\title{
Ensuring Māori student success and inclusion of te aō Māori through initial teacher education
}

\author{
Hiria McRae \& Robin Averill \\ Victoria University of Wellington
}

\begin{abstract}
Teacher commitment to Te Tiriti o Waitangi is emphasised within the latest Code of Professional Responsibility and Standards for the Teaching Profession (Education Council, 2017). Teachers must explicitly demonstrate commitment to tangata whenuatanga and Te Tiriti o Waitangi. This mandate is encouraging for Māori education needs and aspirations. We describe the use of a culturally sustaining teacher practice framework to examine Māori education policy implementation implications within an initial teacher education te ao Māori course. We explain how course content, delivery and assessment aspects can be critiqued and policy implications identified to illustrate the usefulness of the framework for teacher educators and practising teachers. We demonstrate how the framework can be a useful tool for teacher educators to examine culturally sustaining practice in preparing themselves and student teachers to work effectively with indigenous learners.
\end{abstract}

Keywords: Māori education, teacher education, education policy, culturally sustaining teacher practice

\section{Background}

Almost twenty years ago Professor Mason Durie introduced a framework for Māori educational advancement to respond to a call from Māori to assert tino rangatiratanga or autonomy in meeting the educational needs and aspirations of diverse Māori communities (Durie, 2003). His Māori education framework outlined three goals for Māori education, which included Māori being able to: live as Māori; actively participate as citizens of the world; and enjoy good health and a high standard of living (Durie, 2003). These goals were nationally affirmed in the form of the first national Māori education strategy, Ka Hikitia - Managing for Success 2008-2012 (Ministry of Education, 2008), which was intended to support teachers and schools to improve education outcomes for and with Māori learners. This strategy introduced new statements to the national conversation about Māori education based on Professor Durie's goals. These statements included examining how the New Zealand education system could improve its ability to 'maximise Māori potential' and ensure 'Māori students enjoy education success as Māori' (Ministry of Education, 2008, p. 13).

The Education Review Office (ERO, 2010) reported the initial uptake of Ka Hikitia by schools was positive, with over two thirds of primary and secondary schools including $K a$ Hikitia aims as part of their practice and policies within one year of its release. However, in their critique of the effectiveness of Ka Hikitia, using Māori student voice, Berryman and Eley (2017) note subsequent evaluations of Ka Hikitia by the Office of the Auditor General from 
2012 to 2016 saw uptake as poor due to weak implementation processes led by the Ministry of Education. The potential for Ka Hikitia to be transformational for Māori student success, that reflects Māori needs and aspirations, endorsed by research and supported by Māori is undisputed by the Auditor General (Office of the Auditor General, 2013). Berryman and Eley (2017) argue that the principles outlined in Ka Hikitia are yet to be realised and implemented by policymakers, educators and schools in integral and pragmatic ways to ensure positive shifts for Māori students. Tātaiako - A set of cultural competencies for teachers of Māori students (Ministry of Education, 2011) - was developed in partnership between the New Zealand Teaching Council and Ministry of Education as a complementary resource for teachers to align with to help implement the expectations and aims of Ka Hikitia. This resource is discussed later in this article to show examples of what it offers towards addressing the lack of substantial pragmatic implementation of current Māori education policy.

The last twenty years has also seen the emergence of iwi (tribal) focused curriculum development, education strategies and research. For example, in 2008 the Tuhoe Education Authority developed their own curriculum, based on Tuhoe mātauranga (knowledge), reo (language) and tikanga (protocols) which has been implemented by a range of early childhood, primary, secondary and tertiary learning environments in the Tuhoe region (www.ero.govt.nz/reports/Tuhoe). Iwi-led education research has also emerged in the last ten years, such as the Te Arawa-based project Ka Awatea, which examined Māori student success in a range of Rotorua secondary schools using methodologies informed by a set of success characteristics attributed to Te Arawa ancestry (Macfarlane, Webber, Cookson-Cox, \& McRae, 2014). These examples of iwi-led education initiatives reflect kaupapa Māori theory and practice, encouraging Māori to develop and implement Māori solutions to meet Māori needs and aspirations (Smith, 1997).

\section{Current education policy and Māori}

The current teaching profession code of practice in Aotearoa has explicit expectations of teachers in addressing their commitment to Te Tiriti o Waitangi through partnerships with iwi (Education Council, 2017). Te Tiriti o Waitangi is Aotearoa's founding document between the British Crown and indigenous Māori, promising a relationship guaranteeing both groups' partnership, protection and participation (Te Puni Kokiri, 2001). These principles are yet to be realised for Māori, with current Aotearoa society reflecting Eurocentric policy and practices, including education structures, curriculum, teacher education and schooling. Ngā Tikanga Matatikia, Ngā Paerewa Our Code, Our Standards, The Code of Professional Responsibility and Standards for the Teaching Profession in Aotearoa provides Māori communities with an encouraging assurance that the educational needs and aspirations of Māori children will be addressed. In the 'Design for learning' standard, teachers are required to:

- design and plan culturally responsive, evidence-based approaches that reflect the local community and Te Tiriti o Waitangi partnership in New Zealand.

- harness the rich capital that learners bring by providing culturally responsive and engaging contexts for learners. (Education Council, 2017, p. 20) 
In addition, the 'Teaching' standard requires teachers to:

- specifically support the educational aspirations for Māori learners, taking shared responsibility for these learners to achieve educational success as Māori. (Education Council, 2017, p. 20)

The code also expects Māori mātauranga (knowledge), reo (language) and tikanga (protocols) to be modelled and taught in Aotearoa classrooms to all students. Specifically, in the 'Te Tiriti o Waitangi partnership' standard teachers are required to:

Demonstrate commitment to tangata whenuatanga and Te Tiriti o Waitangi partnership in Aotearoa New Zealand. (Teachers are expected to):

- understand and recognise the unique status of tangata whenua in Aotearoa New Zealand.

- understand and acknowledge the histories, heritages, languages and cultures of partners to Te Tiriti o Waitangi.

- practise and develop the use of te reo and tikanga Māori. (Education Council, 2017, p. 18)

Policy expectations are made clear in the current Aotearoa teaching practice code of standards (Education Council, 2017), the current Māori education strategy Ka Hikitia (Ministry of Education, 2009, 2013), and Māori cultural competency guidelines Tātaiako (Ministry of Education, 2011). However, they do not address how these can be successfully implemented by teachers to ensure an integral commitment to Te Tiriti o Waitaingi, and te ao Māori is part of their practice. The latest expectations of initial teacher education providers by the New Zealand Teaching Council also reference aspects of Tātaiako within their examples of how student teachers could be assessed against the current standards (Teaching Council, 2019). For example, to meet the 'Te Tiriti o Waitangi' standard, a student teacher:

- shows, and requires of all learners, respect for tikanga Mãori.

- uses te reo naturally and accurately in his/her interactions with learners.

- in their everyday practice with Māori learners ensures that his/her knowledge, language, culture and experience is affirmed.

- is proactive in finding opportunities to integrate Māori language and contexts into teaching for all learners. (Teaching Council, 2019, Appendix 1, p. 4)

These examples from policy lack detail as to how student teachers can show an integral commitment to Te Tiriti o Waitaingi and te ao Māori as part of their practice. Student teacher engagement with culturally sustaining pedagogy which reflects the principles of Te Tiriti o Waitangi (Te Puni Kokiri, 2001) and te ao Māori could support ensuring policy is strongly embedded in practice.

\section{Culturally sustaining pedagogy and Māori}

Culturally sustaining pedagogy has built upon culturally responsive pedagogy intentions. Gay's (2010) definition of culturally responsive pedagogy asserts student learning and wellbeing are strongly enhanced when knowledge, personal experiences, and world-views 
associated with a student's culture are incorporated into the classroom. Ladson-Billings (2009) adds students need to be empowered holistically through culturally responsive practices. Paris' (2012) definition of culturally sustaining pedagogy expands on these assertions by promoting learning opportunities where students and teachers deliberately perpetuate, foster and sustain cultural knowledge, practices and language. Māori student achievement initiatives, based on culturally responsive practices, have been a strong focus in Aotearoa for almost twenty years (Bishop, Berryman, Tiakiwai, \& Richardson, 2003), yet many Māori learners are still not experiencing these proven positive approaches (Hynds, Averill, Hindle, \& Meyer, 2017). Therefore, it is imperative that our student teachers are being provided with learning opportunities that support them in providing culturally sustaining pedagogy for their Māori students as they may not have experienced such teaching in their own school learning and may not experience it on their practice. Recent studies from the University of Canterbury (UoC) in Aotearoa provide examples of how their institution supports student teachers in engaging with culturally sustaining practices and te ao Māori (Clarke, Macfarlane, \& Macfarlane, 2018; Fickel, Abbiss, Brown, \& Astall, 2018; Wilson, McChesney, \& Brown, 2017).

A description of how UoC took an opportunity with the development of a new teacher education programme to strengthen the te ao Māori content with practical links to Tātaiako and Ka Hikitia was the focus of one study (Clarke et al., 2018). This study was complemented by Fickel et al. (2018) with their explanation of how the same programme was developed in consultation with local iwi. Both studies described a culturally responsive framework used to monitor student teacher confidence, competence and progressive expertise with te ao Māori (Clarke et al., 2018; Fickel et al., 2018). The descriptions of culturally sustaining practices expected of student teachers, outlined in both studies, were at times broad with limited detail about what each dimension might look like in practice. For example, within the wānanga dimension of the framework, student teachers are expected to "value àkonga voice and feedback in the lesson" (Fickel et al., 2018, p. 290). First, there is no detail about what this would look like in practice and second, this is a fundamental expectation a student teacher would have of all students and is not specifically derived from the te ao Māori definition of wānanga. Therefore, the description is not a te ao Māori culturally sustaining example of practice. The third study from UoC examined a group of student teachers' understanding of Tātaiako within the context of their mathematics education course (Wilson et al., 2017). Student teachers were asked to provide examples of what the five Māori cultural competencies of wānanga, whanaungatanga, manaakitanga, ako and tangata whenuatanga (Ministry of Education, 2011) looked like in their studies and within their own practice in schools. Students were asked to reflect on examples of explicit then implicit interpretations of Tātaiako modelled during course work and during their work out in schools (Wilson et al., 2017). Like the critique of the two other UoC studies (Clarke et al., 2018; Fickel, et al., 2018) some of the examples of practices were broad and Māori concepts generalised with no explicit links to te ao Māori. For example, wānanga was associated with working in pairs, groups, involving discussion but not framed with an understanding of how this concept is uniquely Māori and in practice meets the needs of Māori learners. In their study about enhancing student teacher self-efficacy beliefs to teach priority learners, Hansen, Sewell, Fernando, and Safa (2017) asked students to identify what aspects of their teacher education programmes strengthened culturally sustaining practices. The student teachers identified modelling from their teaching staff and teachers in schools was a key enabler. This finding supports our argument for student teachers to have culturally sustaining practices explained 
and critiqued, and expectations explicitly modelled to them by teacher educators and their teacher mentors in schools.

We support the efforts of current policymakers in teacher education that require teachers to explicitly demonstrate commitment to tangata whenuatanga and Te Tiriti o Waitangi, as well as the development of te ao Māori focused culturally sustaining frameworks by teacher educators. However, we assert that student teachers require explicit examples within their initial teacher education training of how they could implement culturally sustaining practices to meet the needs of Māori students and engage with te ao Māori. Therefore, we ask the question, "How can teacher educators examine their ability, to develop student teachers' transformational practice for te ao Māori?" Consequently, we have developed a culturally sustaining teacher practice framework (introduced later in this article) and have used it to examine Māori education policy implementation implications of an initial teacher education te ao Māori course. Course content, delivery and assessment aspects were critiqued, and policy implications identified. One outcome for developing this framework has been to support teacher educators and practising teachers to examine their culturally sustaining practice in preparing themselves and student teachers to work effectively with indigenous learners.

First, an explanation of the background of the development of this latest iteration of a culturally sustaining framework to support meeting the needs of Māori learners, as well as engaging all learners in Aotearoa New Zealand classrooms with te ao Māori, is offered. Second, we use the framework to examine a te ao Māori teacher education course, to critique its usefulness for teacher educators to examine their ability to develop student teachers' transformational practice for te ao Māori. This examination also aims to reveal any areas within the te ao Māori course that need further refinement to better support our student teachers and to improve our practice as teacher educators. Finally, we offer some reflections for teacher educators and practising teachers within Aotearoa New Zealand and internationally to consider in their own delivery of culturally sustaining teaching practices aimed at meeting the needs and aspirations of indigenous and minority learners and their communities.

\section{Te Ao Māori Culturally Sustaining Teacher Practice Framework}

Mā te rongo, ka mōhio.

Mā te mōhio, ka mārama.

Mā te mārama, ka mātau.

Mā te mātau, ka ora.
Through perception, comes awareness.

Through awareness, comes understanding.

Through understanding, comes wisdom.

Through wisdom, comes well-being.

This whakatauki or proverb is commonly used to describe the progression or development of learning and the contribution to one's overall well-being from a Māori perspective. It was used recently by the UoC to guide culturally sustaining teacher practice frameworks for their student teachers (Clarke et al., 2018; Fickel et al., 2018). We also referenced this whakatauki in our initial research, examining how our faculty was developing student teacher confidence and competence to teach indigenous learners (Averill \& McRae, 2019). We consider these wise words applicable to our commitment to the continual development and critique of tools to support student teachers to meet the needs of Māori learners and engage with te ao Māori. 
Despite recent national and iwi led education initiatives, many Māori learners are not having their educational needs met nor their aspirations achieved (Education Review Office, 2010). Research has shown a contributing component to this dilemma is the lack of opportunities for Māori learners to experience culturally responsive or sustaining teaching (Hynds et al., 2017). Graduating teachers have reported that they often lack confidence in their ability to maximise the learning of Māori students and to work collaboratively with Māori whānau (Education Review Office, 2017).

The authors of this article first introduced their culturally sustaining teacher practice framework in a paper examining how their faculty prepares teachers to be confident and competent teachers of Māori learners and model and teach te ao Māori in their classrooms (Averill \& McRae, 2019). The main categories, Accommodation, Reformation and Transformation, were adapted from a framework used to compare the depth of knowledge, critical thinking, and commitment to change in response to issues of environmental sustainability (Renert, 2011; Sterling, 2004). We added a fourth category, Representation, a fundamental element to ensure our commitment to the principles of Te Tiriti o Waitangi (Te Puni Kokiri, 2001), New Zealand's founding document (Averill \& McRae, 2019). Accommodation responses focus on content, knowledge, and knowing 'about' an issue rather than involving any elements of challenge to the status quo. Reformation responses, in contrast, show use of critical reflection on assumptions implicit in the status quo and accommodation-style responses. They demonstrate learning for culturally sustaining teaching in that, through critical thinking, they foster the development of values and capability in tangible ways. Transformation responses demonstrate education as culturally sustainable in that culturally sustaining practice is integrated within the education process and viewed as a way of developing future education. Representation enables us to comment on the extent to which culturally sustaining pedagogy initiatives have been developed in partnership with Māori. Representation encompasses prioritising Māori expectations, perspectives, knowledge, and experiences in discussions about and actions promoting culturally sustaining intentions and practices through Māori involvement in inception, development, and implementation.

The framework was developed by the two authors of this article and critique has been sought through sharing with recent teacher trainees within a te ao Māori-focused course and as an online survey with postgraduate education students and initial teacher education academics. We also plan to seek critique from our faculty Māori advisory committee. After using the framework to examine culturally sustaining practice within our faculty (Averill \& McRae, 2019), we wanted to develop a further iteration that could scrutinise the effectiveness of our courses specifically focused on engaging our student teachers with te ao Māori. The categories of accommodation, reformation, transformation and representation remain the core component describing examples of culturally sustaining teacher practice to ensure Māori student success and engage with te ao Māori. The redevelopment of the framework includes the addition of two sets of principles vital for culturally sustaining teaching and learning practices in Aotearoa New Zealand. The first set is directly drawn from Tātaiako - A Set of Cultural Competencies for Teachers of Māori (Ministry of Education, 2011). These include Tātaiako's over-arching commitment to Te Tiriti o Waitangi and fundamental Māori concepts, whanaungatanga, ako, manaakitanga, wananga and tangata whenuatanga articulated in Tātaiako as cultural competencies. Tātaiako was preferred because its overall purpose is to support teachers and teacher educators to engage positively with Māori learners and te ao Māori. It has been utilised and endorsed by teachers, principals and teacher 
educators (Averill et al., 2014; McLeod \& Kenrick, 2013; Patara, 2012; Wilson et al., 2017). We assert that Tátaiako is a foundational resource that needs to be continuously referenced, interpreted and implemented to meet the needs of Māori learners and engage with te ao Māori.

The second set of principles has been found to contribute to Māori student success if understood and implemented by teachers and schools, and taken directly from Ka AwateaAn Iwi Case Study of Māori Student Success (Macfarlane et al., 2014). These include mana tangatarua, mana whānau, mana motuhake, mana tū, and mana ūkaipō. These principles arose from findings within a research project grounded in kaupapa Māori principles because it was conducted by Māori researchers, with Māori participants, for Māori outcomes within their own tribal region (Smith, 1997). The research and resulting principles were founded in one Māori community's needs and aspirations for their Māori students, therefore were aligned with our commitment to meeting the needs and expectations of Māori communities through our work with student teachers. We acknowledge these principles have a broader meaning and implications for Māori; however, we have chosen to discuss them within a Māori education context. This latest framework is entitled Ensuring Māori student success and inclusion of te aō Māori through initial teacher education (Table 1). 
Table 1.

Ensuring Māori student success and inclusion of te ao Māori through initial teacher education

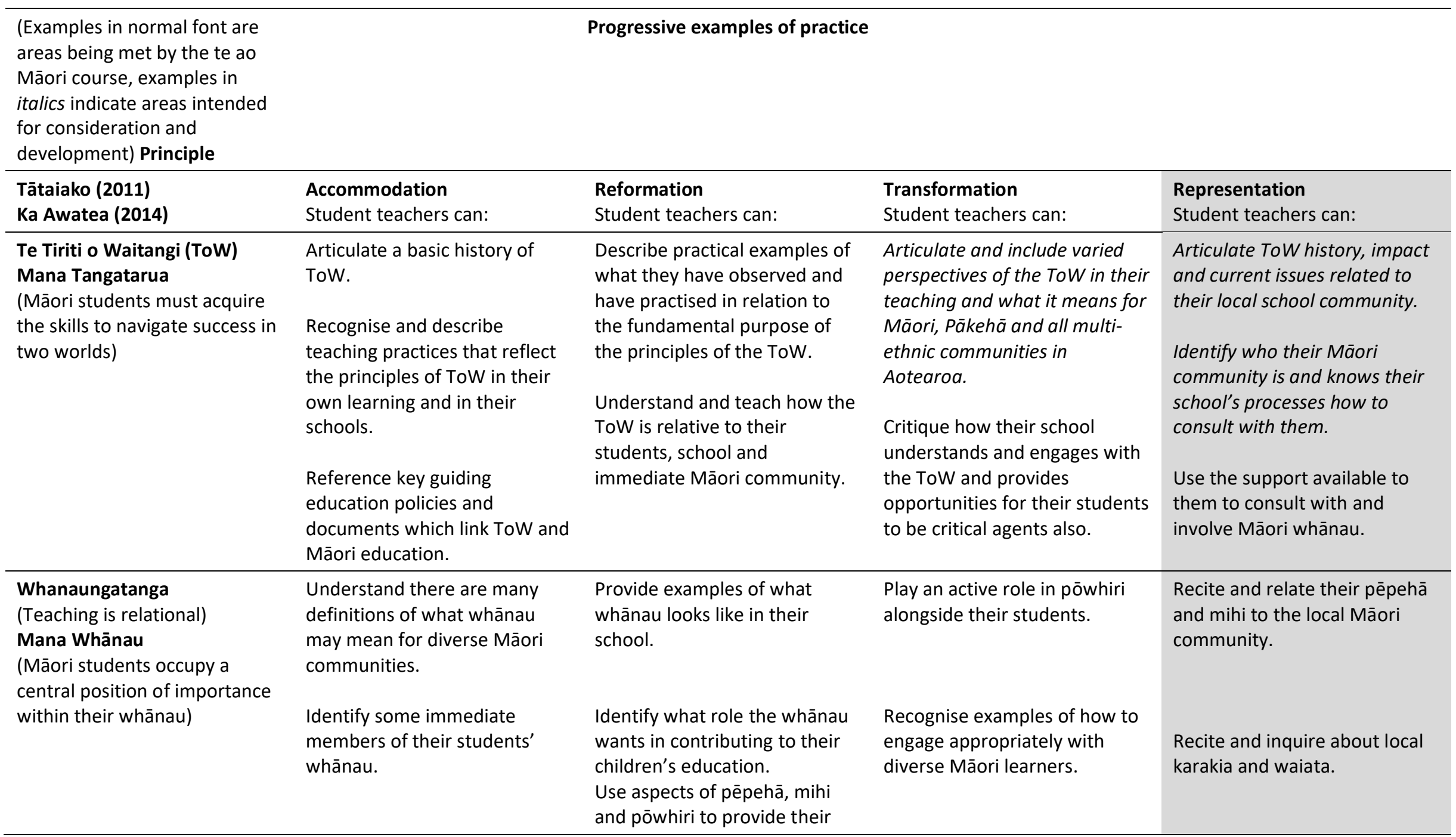




\begin{tabular}{|c|c|c|c|c|}
\hline $\begin{array}{l}\text { (Examples in normal font are } \\
\text { areas being met by the te ao } \\
\text { Māori course, examples in } \\
\text { italics indicate areas intended } \\
\text { for consideration and } \\
\text { development) Principle }\end{array}$ & & Progressive examples of practice & & \\
\hline $\begin{array}{l}\text { Tātaiako (2011) } \\
\text { Ka Awatea (2014) }\end{array}$ & $\begin{array}{l}\text { Accommodation } \\
\text { Student teachers can: }\end{array}$ & $\begin{array}{l}\text { Reformation } \\
\text { Student teachers can: }\end{array}$ & $\begin{array}{l}\text { Transformation } \\
\text { Student teachers can: }\end{array}$ & $\begin{array}{l}\text { Representation } \\
\text { Student teachers can: }\end{array}$ \\
\hline & $\begin{array}{l}\text { Articulate correct } \\
\text { pronunciation of Māori names } \\
\text { and words. } \\
\text { Share their pēpehā and mihi. } \\
\text { Recognise good examples of } \\
\text { the use of reo and tikanga in } \\
\text { their own learning and schools. } \\
\text { Understand and has } \\
\text { participated in the powhiri } \\
\text { process. } \\
\text { Recite karakia. }\end{array}$ & $\begin{array}{l}\text { students with opportunities to } \\
\text { share about themselves and } \\
\text { learn about each other's } \\
\text { backgrounds. } \\
\text { Include aspects of pēpehā,, } \\
\text { mihi and powhiri to welcome } \\
\text { and introduce visitors to their } \\
\text { classroom. } \\
\text { Use appropriate karakia for } \\
\text { different occasions and parts of } \\
\text { the school day. }\end{array}$ & $\begin{array}{l}\text { Provide a wide range of } \\
\text { teaching strategies that ensure } \\
\text { a sense of belonging for Māori } \\
\text { students and all students using } \\
\text { Māori concepts and pedagogy. }\end{array}$ & $\begin{array}{l}\text { Identify, teach to, and review } \\
\text { the education needs and } \\
\text { aspirations of their whānau on } \\
\text { a regular basis. } \\
\text { Articulate and support the role } \\
\text { of whannau in their students' } \\
\text { learning. }\end{array}$ \\
\hline $\begin{array}{l}\text { Ako } \\
\text { (Teaching requires diverse } \\
\text { pedagogical approaches) } \\
\text { Mana motuhake } \\
\text { (A positive sense of Māori } \\
\text { identity is experienced by } \\
\text { students through their } \\
\text { learning) }\end{array}$ & $\begin{array}{l}\text { Understand examples of } \\
\text { pedagogies important to Māori } \\
\text { (e.g., waiata (Māori songs), } \\
\text { purākau (Māori writing), } \\
\text { whakataukī, pakiwaitara (Māori } \\
\text { storytelling). } \\
\text { Recognise examples of Māori } \\
\text { pedagogy being modelled to } \\
\text { them in their own learning and } \\
\text { in their schools. }\end{array}$ & $\begin{array}{l}\text { Articulate and use examples of } \\
\text { Māori pedagogy being } \\
\text { modelled to them in } \\
\text { appropriate and innovative } \\
\text { ways. }\end{array}$ & $\begin{array}{l}\text { Co-construct the use of Māori } \\
\text { pedagogy with their students } \\
\text { to meet their needs and } \\
\text { aspirations. }\end{array}$ & $\begin{array}{l}\text { Can identify and implement } \\
\text { examples of pedagogy uniquely } \\
\text { associated with their school's } \\
\text { Māori community. }\end{array}$ \\
\hline
\end{tabular}




\begin{tabular}{|c|c|c|c|c|}
\hline $\begin{array}{l}\text { (Examples in normal font are } \\
\text { areas being met by the te ao } \\
\text { Māori course, examples in } \\
\text { italics indicate areas intended } \\
\text { for consideration and } \\
\text { development) Principle }\end{array}$ & & Progressive examples of practice & & \\
\hline $\begin{array}{l}\text { Tātaiako (2011) } \\
\text { Ka Awatea (2014) }\end{array}$ & $\begin{array}{l}\text { Accommodation } \\
\text { Student teachers can: }\end{array}$ & $\begin{array}{l}\text { Reformation } \\
\text { Student teachers can: }\end{array}$ & $\begin{array}{l}\text { Transformation } \\
\text { Student teachers can: }\end{array}$ & $\begin{array}{l}\text { Representation } \\
\text { Student teachers can: }\end{array}$ \\
\hline $\begin{array}{l}\text { Manaakitanga } \\
\text { (Teaching requires critical } \\
\text { thinking about equity) } \\
\text { Mana motuhake } \\
\text { (A positive sense of Māori } \\
\text { identity is role modelled by } \\
\text { teachers) }\end{array}$ & $\begin{array}{l}\text { Articulate Māori practices of } \\
\text { respect, inclusion and service } \\
\text { to others such as mihi } \\
\text { whakatau and koha. } \\
\text { Understand there are diverse } \\
\text { views of what it means to be } \\
\text { Māori. }\end{array}$ & $\begin{array}{l}\text { Model appropriate practices of } \\
\text { mihimihi and koha with their } \\
\text { students within the classroom } \\
\text { to acknowledge and celebrate } \\
\text { others' contributions and } \\
\text { achievements. } \\
\text { Include a range of positive } \\
\text { perspectives of what it means } \\
\text { to be Māori in their teaching. }\end{array}$ & $\begin{array}{l}\text { Model appropriate practices of } \\
\text { mihimihi and koha in the wider } \\
\text { school to acknowledge and } \\
\text { celebrate others' contributions } \\
\text { and achievements. } \\
\text { Work alongside their students } \\
\text { to examine what it means to be } \\
\text { a positive contribution as } \\
\text { Māori in their communities. }\end{array}$ & $\begin{array}{l}\text { Articulate practices of mihimihi } \\
\text { and koha that are unique to the } \\
\text { local Māori community. } \\
\text { Identify who in their school can } \\
\text { connect with Māori role models } \\
\text { within their community. }\end{array}$ \\
\hline $\begin{array}{l}\text { Wananga } \\
\text { (Teaching requires } \\
\text { co-construction) } \\
\text { Mana Tū } \\
\text { (Māori students can develop a } \\
\text { sense of courage and } \\
\text { resilience) }\end{array}$ & $\begin{array}{l}\text { Recognise and implement } \\
\text { opportunities for students to } \\
\text { participate in shared teaching } \\
\text { and learning experiences. }\end{array}$ & $\begin{array}{l}\text { Articulate and use with their } \\
\text { students' discussion strategies } \\
\text { that reflect whaikōrero and } \\
\text { karanga practices. }\end{array}$ & $\begin{array}{l}\text { Motivate students to lead and } \\
\text { facilitate teaching and learning } \\
\text { experiences that reflect } \\
\text { wānanga practices. }\end{array}$ & $\begin{array}{l}\text { Articulate who can support } \\
\text { them with involving Māori } \\
\text { whānau in their classroom } \\
\text { programme. }\end{array}$ \\
\hline $\begin{array}{l}\text { Tangata Whenuatanga } \\
\text { (Teaching builds on learners' } \\
\text { foundational experiences and } \\
\text { knowledge) } \\
\text { Mana Ukaipo } \\
\text { (Place-based learning is } \\
\text { important for Māori student } \\
\text { learning and connection to } \\
\text { place) }\end{array}$ & $\begin{array}{l}\text { Share a basic understanding of } \\
\text { the history of Māori education } \\
\text { and the effects of colonisation } \\
\text { on Māori language, knowledge } \\
\text { and identity. } \\
\text { Participate in teaching and } \\
\text { learning activities at their local } \\
\text { marae. }\end{array}$ & $\begin{array}{l}\text { Implement the history, } \\
\text { language and knowledge } \\
\text { associated with their local } \\
\text { Māori community in their } \\
\text { teaching. }\end{array}$ & $\begin{array}{l}\text { Provide opportunities for their } \\
\text { students to critique and } \\
\text { examine a wide range of issues } \\
\text { associated with their local } \\
\text { Māori community. } \\
\text { Seek opportunities to teach at } \\
\text { local marae and places of } \\
\text { significance for local Māori. }\end{array}$ & $\begin{array}{l}\text { Articulate local iwi aspirations. } \\
\text { Access support with including } \\
\text { local reo, tikanga and } \\
\text { mātauranga in their classroom. }\end{array}$ \\
\hline
\end{tabular}




\section{Evaluation Process}

The te ao Māori focused course we have chosen to examine, using this new redeveloped framework (Table 1), is one of four compulsory professional practice courses within a oneyear Master of Teaching and Learning programme for primary and secondary student teachers. The overall aim of this course is to provide student teachers with an opportunity to critically examine their commitment to the Treaty of Waitangi. The endeavour is to support them to be confident in their ability to engage students with te ao Māori educational realities and to recognise and implement culturally sustaining pedagogies. The complementary endeavour is to prepare students to use evidence-based approaches that meet the diverse needs of Māori students in schools led by an inquiry question, "How can I contribute to Māori student success?" Our intention for this course is to provide enough support to our student teachers so that they engage all their students with te aō Māori through their teaching, as appropriate to their communities and contexts. We also want to ensure they are prepared for the current context of expectations within teacher education in Aotearoa.

Our guiding question used to critique our te ao Māori focused course was "How can teacher educators examine their ability, to develop student teachers' transformational practice for te ao Māori?" The content, delivery and assessment within the course were evaluated by how aspects of each supported student teachers in their ability to undertake the examples of teaching practice provided in the framework (Table 1). An explanation of these judgements will be described in the findings section of this article.

\section{Findings}

The following table (Table 2) is a summary of findings from the analysis of the teacher education te ao Māori focused course using our latest framework (Table 1) to identify areas of development or for further examination. 
Table 2.

Effectiveness of a teacher education te ao Māori course: Areas for development or for further consideration

\begin{tabular}{|c|c|c|}
\hline Principle & Progressive examples of practice & \\
\hline $\begin{array}{l}\text { Tātaiako (2011) } \\
\text { Ka Awatea (2014) }\end{array}$ & $\begin{array}{l}\text { Transformation } \\
\text { Students can: }\end{array}$ & $\begin{array}{l}\text { Representation } \\
\text { Students can: }\end{array}$ \\
\hline $\begin{array}{l}\text { Te Tiriti o Waitangi (ToW) } \\
\text { Mana Tangatarua } \\
\text { (Māori students must acquire the } \\
\text { skills to navigate success in two } \\
\text { worlds) }\end{array}$ & $\begin{array}{l}\text { Articulate and include varied } \\
\text { perspectives of the ToW in their } \\
\text { teaching and what it means for } \\
\text { Māori, Pākehā and all multi- } \\
\text { ethnic communities in Aotearoa. }\end{array}$ & $\begin{array}{l}\text { Articulate Tow history, impact } \\
\text { and current issues related to their } \\
\text { local school community. } \\
\text { Identify who their Māori } \\
\text { community is and knows their } \\
\text { school's processes how to consult } \\
\text { with them. }\end{array}$ \\
\hline
\end{tabular}

\section{Whanaungatanga}

(Teaching is relational)

\section{Mana Whānau}

(Māori students occupy a central position of importance within their whānau)

\section{Ako \\ (Teaching requires diverse pedagogical approaches) \\ Mana motuhake}

(A positive sense of Māori identity is experienced by students through their learning)

\section{Manaakitanga}

(Teaching requires critical thinking about equity)

Mana motuhake

(A positive sense of Māori identity is role modelled by teachers)

\section{Wananga}

(Teaching requires

co-construction)

\section{Mana Tū}

(Māori students can develop a sense of courage and resilience)

\section{Tangata Whenuatanga}

(Teaching builds on learners' foundational experiences and knowledge)

\section{Mana Ukaipo}

(Place-based learning is important for Māori student learning and connection to place)

Identify, teach to, and review the education needs and aspirations of their whānau on a regular basis.

Articulate and support the role of whānau in their students' learning.

Can identify and implement examples of pedagogy uniquely associated with their school's Māori community.

Articulate practices of mihimihi and koha that are unique to the local Māori community. Identify who in their school can connect with Māori role models within their community.

Articulate who can support them with involving Māori whānau in their classroom programme.

Seek opportunities to teach at local marae and places of significance for local Māori.
Articulate local iwi aspirations.

Access support including local reo, tikanga and mātauranga into their classroom. 
The initial critique highlighted areas for development not confined to or the responsibility of a te ao Māori teacher education course to address (Table 2). The first area of concern is that our faculty is reliant on the schools our student teachers spend time in for their teaching experience to engage them with the local context and Māori communities. Therefore, we need to be proactive about ensuring we keep our relationships between our faculty and our supporting schools current by being in regular contact and acknowledging their contribution to teacher education. Second, we also have a responsibility as a faculty to actively develop and nurture formal partnerships with our local context and Māori communities to role model expectations to our schools and students. Finally, as a faculty, it is important that we keep our programmes up to date and aligned with current issues regarding our commitment to Te Tiriti o Waitangi and te ao Māori, to ensure our students' confidence is being expanded.

Further critique identified areas of improvement that could be addressed through collaboration between our faculty and our school communities. The first area is the need for both parties to understand Te Tiriti o Waitangi in relation to our local context and schools supporting our student teachers. This understanding could include an historical, social, political and current perspective of Te Tiriti. The other area that could be improved through our faculty and schools working together is examining the growing multi-ethnic schooling population in Aotearoa New Zealand in relation to Te Tiriti o Waitangi. It is important to model to our student teachers that we consider Te Tiriti to be a living and current document which has relevancy for everyone teaching and learning in Aotearoa New Zealand.

The final layer of analysis recognised further areas of concern that we consider are mainly reliant on schools addressing and that also need to be supported by our faculty. The first area is to ensure our student teachers know who their local Māori communities are and have the support within their schools to know how to consult and work alongside them. This is a concern as we are assuming as a faculty that our participating schools have this knowledge and ability, which in some instances may not be so. It is the responsibility of our faculty to not assume our students are being supported by connecting with Māori communities and identify processes to ensure we work with schools that do or support them with developing and nurturing these relationships. The second area of concern is related to the first in that if you have a relationship with your local Māori communities then you possibly have access to Māori tikanga, reo, mātauranga, marae, wāhi tapu and examples of applicable pedagogy. The final area of concern is the need for schools to understand their Māori whānau's needs and aspirations for their tamariki and whānau expectations of schools. The school and whānau also need to agree as to what role the whānau contribute to their tamariki's education.

In summary, the examination of how one te ao Māori-focused course supports student teachers through the lens of a culturally sustaining framework has highlighted an overall key expectation, specifically, the need for teacher educators and schools to improve their practice in relation to Te Tiriti o Waitangi and te ao Māori to maximise the opportunities for policy implementation within initial teacher education. Both groups need to be proactive about ensuring an integral understanding of local context and nurturing and maintaining integral relationships with Māori communities. Each group also needs to acknowledge each other and associated Māori communities for their contributions to support shared student teachers. Understanding Te Tiriti o Waitangi in relation to local context and schools supporting our student teachers is also vital. Finally, it is critical for teacher educators to demonstrate to student teachers the relevancy of Te Tiriti in contemporary societal and political issues affecting education in Aotearoa New Zealand. 


\section{Discussion}

In this section we provide a further layer regarding what the commitment to Te Tiriti o Waitangi could look like in a faculty of teacher educators. Examples include the need to have Māori representation from teaching and professional staff and senior management roles within teacher education providing advice and input into policy development and implementation (Clarke et al., 2018; Fickel et al., 2018; Wilson et al., 2017). Understanding and enacting a commitment to Te Tiriti o Waitangi by teacher educators across all courses within all programmes is also necessary (Fickel et al., 2018). Finally, teacher educators, their faculties and institutions need to be active partners in having reciprocal relationships with local Māori communities alongside teachers and schools (Clarke et al., 2018; Fickel et al., 2018). Further examples of what this commitment could look like in practice specifically for our faculty have been aligned with the two new sets of principles added to our culturally sustaining teacher practice framework. These expectations are also applicable to the schools we work alongside if our aim is to provide our student teachers with positive examples of engaging with te ao Māori in their studies and on teaching experience.

\section{Te Tiriti o Waitangi and Mana tangatarua}

It is fundamental for our faculty to understand Te Tiriti o Waitangi implications past, present and future in relation to our current and developing education context, also seeking out and acknowledging varied perspectives. Specifically, we need to be able to identify who our Māori community is and know how to engage reciprocally.

\section{Whanaungatanga and Mana Whānau}

As teacher educators we need to provide and model to our student teachers strategies to help them engage with their schools to gain an understanding of the needs and aspirations of their Māori whānau and community.

\section{Ako and Mana motuhake}

It is our responsibility to have knowledge and understanding of broad examples of Māori pedagogy and model these within all learning areas of our teacher educator programmes. It is also important to examine and implement unique examples of pedagogy associated with our Māori communities. We also need to have shared understanding and expectations of culturally sustaining practices with the schools we work alongside.

\section{Manaakitanga and Mana motuhake}

Like expectations associated with 'ako' and 'mana motuhake,' teacher educators within our faculty should be able to understand and demonstrate practices of mihimihi (acknowledgements) and koha (contribution) that are unique to local Māori communities. A willingness and ability to connect with Māori role models within our community is also a vital attribute of a committed teacher educator. 


\section{Wananga and Mana Tū}

The ability to demonstrate positive relationships with all students and their whānau is a fundamental expectation of student teachers. Therefore, teacher educators within our faculty need to model their ability to engage reciprocally with Māori whānau.

\section{Tangata Whenuatanga and Mana Ukaipo}

Of equal importance, our faculty of teacher educators should be able to engage with local marae and places of significance for local Māori as well as articulate local iwi needs and aspirations. Through our connections to local iwi, our student teachers should be able to access support with understanding local reo, tikanga and mātauranga.

\section{Conclusion}

Mā te rongo, ka mōhio.

Mā te mōhio, ka mārama.

Mā te mārama, ka mātau.

Mā te mātau, ka ora.
Through perception, comes awareness.

Through awareness, comes understanding.

Through understanding, comes wisdom.

Through wisdom, comes well-being.

This whakatauki illustrates our commitment to the continual development and critique of tools to support student teachers to meet the needs of Māori learners and engage with te ao Māori. The current manifestation of our commitment is the redevelopment of a culturally sustaining teacher practice framework for teacher educators and practising teachers. Teacher commitment to Te Tiriti o Waitangi is emphasised with the latest Code of Professional Responsibility and Standards for the Teaching Profession, and Māori education initiatives Ka Hikitia and Tātaiako. Teachers must explicitly demonstrate commitment to tangata whenuatanga and Te Tiriti o Waitangi. This mandate is encouraging for Māori education needs and aspirations. We aim to support meeting these expectations through the continual examination of our own culturally sustaining teacher practices.

Therefore, we have provided an explanation of how we developed this latest iteration of a culturally sustaining framework to give support to meeting the needs of Māori learners as well as engaging all learners in Aotearoa New Zealand classrooms with te ao Māori. Second, we outlined how we used the framework to examine a te ao Māori teacher education course, to critique its usefulness for teacher educators to examine their ability, and to develop student teachers' transformational practice for te ao Māori. This examination revealed areas within the te ao Māori course that need further development to better support our student teachers and improve our practice as teacher educators. Finally, we have provided some Ka pai ideas for teacher educators and teachers within Aotearoa and internationally to consider in their own delivery of culturally sustaining teaching practices aimed at meeting the needs and aspirations of indigenous and minority learners and their communities. 


\section{References}

Averill, R., Hindle, R., Hynds, A., Meyer, L., Penetito, W., Taiwhati, M., Hodis, F., \& Faircloth, S.C. (2014). "It means everything doesn't it?" Interpretations of Māori students achieving and enjoying educational success "as Māori." Set: Research Information for Teachers, 2, 33-40.

Averill, R., \& McRae, H. (2019). A framework for evaluating initial mathematics teacher education towards enhancing culturally responsive and sustaining practice. The Educational Forum, 83, 1-14. doi.10.1080/00131725.2019.1599657

Berryman, M., \& Eley, E. (2017). Succeeding as Māori: Māori students' views on our stepping up to the Ka Hikitia challenge. New Zealand Journal Education Studies, 52, 93-107.

Bishop, R., Berryman, M., Tiakiwai, S., \& Richardson, C. (2003). Te Kotahitanga: The experiences of year 9 and 10 Māori students in mainstream classrooms. Wellington, New Zealand: Ministry of Education.

Clarke T. H., Macfarlane S., \& Macfarlane A. (2018). Integrating indigenous Māori frameworks to ignite understandings within initial teacher education-and beyond. In P. Whitinui, C. Rodriguez de France, \& O. Mclvor (Eds.), Promising practices in indigenous teacher education. Singapore: Springer.

Durie, M. (2003). Ngā Kāhui Pou: Launching Māori futures. Wellington, New Zealand: Huia.

Education Council. (2017). Our code our standards: Ngā tikanga matatika Ngā paerewa. Wellington, New Zealand: Author.

Education Review Office. (2010). Promoting success for Māori students: Schools' progress. Wellington, New Zealand: Author.

Education Review Office. (2017). Newly graduated teachers: Preparation and confidence to teach. Wellington, New Zealand: Author.

Fickel, L., Abbiss,J., Brown, L., \& Astall, C. (2018). The importance of community knowledge in learning to teach: Foregrounding Māori cultural knowledge to support preservice teachers' development of culturally responsive practice. Peabody Journal of Education, 93(3), 285-294, doi.10.1080/0161956X.2018.1449858

Gay, G. (2010). Culturally responsive teaching: Theory, research, and practice ( $2^{\text {nd }}$ ed.). New York: Teachers College Press.

Hansen, S., Sewell, A., Fernando, S., \& Safa, A. (2017). Enhancing student teacher selfefficacy beliefs to teach priority learners in New Zealand. New Zealand Annual Review of Education, 22, 36c52.

Hynds, A., Averill, R., Hindle, R., \& Meyer, L. (2017). School expectation and student aspirations: The influence of schools and teachers on indigenous secondary students. Ethnicities, 17(4), 546-573.

Ladson-Billings, G. (2009). The dreamkeepers: Successful teachers of African American children, $\left(2^{\text {nd }}\right.$ ed.). San Francisco: Jossey-Bass.

Macfarlane, A., Webber, M., Cookson-Cox, C., \& McRae, H. (2014). Ka Awatea: An iwi case study of Māori students' success. [Manuscript]. Auckland, New Zealand: University of Auckland.

McLeod, J., \& Kenrick, P. (2013). Special interest group report: Tātaiako: Cultural competencies for teachers of Māori learners. Waikato Journal of Education, 18(1). Retrieved from https://doi.org/10.15663/wje.v18i1.150

Ministry of Education. (2008). Ka Hikitia - Managing for success: The Māori education strategy 2008-2012. Wellington, New Zealand: Author. 
Ministry of Education. (2009). Ka Hikitia - Managing for success: The Māori education strategy 2008-2012 (Updated). Wellington, New Zealand: Author.

Ministry of Education. (2011). Tãtaiako. Cultural competencies for teachers of Māori learners. Wellington, New Zealand: Author. Retrieved from https://educationcouncil.org.nz/sites/default/files/Tataiako_0.pdf

Ministry of Education. (2013). Ka Hikitia - Accelerating success: The Māori education strategy 2013-2018. Wellington, New Zealand: Author.

Office of the Auditor General. (2013). Education for Māori: Implementing Ka Hikitia Managing for success. Wellington, New Zealand: Author.

Paris, D. (2012). Culturally sustaining pedagogy: A needed change in stance, terminology and practice. Educational Researcher, 41(3), 93-97.

Patara, L. (2012). Integrating culturally responsive teaching and learning pedagogy in line with Ka Hikitia. Set: Research Information for Teachers, 2, 49-52.

Renert, M. (2011). Mathematics for life: Sustainable mathematics education. For the Learning of Mathematics, 31(1), 20-26.

Smith, G. H. (1997). The development of Kaupapa Māori: Theory and praxis (doctoral thesis). The University of Auckland, New Zealand.

Sterling, S. (2004). Sustainable education: Re-visioning learning and change. Foxhole, UK: Green Books.

Teaching Council. (2019). Initial teacher education programme approval, monitoring and review requirements. Wellington, New Zealand: Author.

Te Puni Kokiri. (2001). He Tirohanga o kawa o Te Tiriti o Waitangi. Wellington, New Zealand: Author.

Wilson, S., McChesney, J., \& Brown, L. (2017). Cultural competencies and planning for teaching mathematics: Preservice teachers responding to expectations, opportunities and resources. Journal of Urban Mathematics Education, 10(1), 95-112.

Hiria McRae is a senior lecturer at Te Puna o Ako Pai, Te Herenga Waka, Victoria University of Wellington. She specialises in teaching pre-service teachers in the areas of mātauranga Māori, te reo Māori, science and technology. Her broad research interests include Māori education, place-based education and education for sustainability. Current projects include examining Māori and Pacific Island tertiary student experience of initial teacher education and culturally sustaining practices for Māori.

hiria.mcrae@vuw.ac.nz

ORCID: http://orcid/0000-0001-5340-5421

Robin Averill is an associate professor at Te Puna o Ako Pai, Te Herenga Waka, Victoria University of Wellington. With a background in secondary teaching and assessment, initial teacher education and teacher professional development, Robin's research focuses on culturally sustaining practice and ways to improve equity of access to achievement, particularly for Indigenous and marginalised learners.

Robin.averill@vuw.ac.nz

ORCID: http://orcid/0000-0002-8941-5565 